\title{
Lignocellulosic fraction of the pericarps of the acorns of Quercus suber and Quercus ilex: isolation, characterization, and biosorption studies in the removal of copper from aqueous solutions
}

\author{
Moubarek Mébarki ${ }^{1, *}$, Kadda Hachem ${ }^{1,2,3}$, Meriem Kaid Harche ${ }^{1}$ \\ ${ }^{1}$ Laboratoire des Productions, Valorisations Végétales et Microbiennes, (LP2VM), Faculté des Sciences de la Nature et de la \\ Vie, Université des Sciences et de la Technologie d'Oran Mohamed Boudiaf, BP 1505, El M'Naouar, 31000 Oran, Algeria \\ ${ }^{2}$ Laboratoire de Biotoxicologie, Pharmacognosie et Valorisation Biologique des Plantes (LBPVBP), Faculté des sciences, \\ Université Dr. Tahar Moulay de Saïda, BP 138 cité ENNASR, 20000 Sä̈da, Algeria \\ ${ }^{3}$ Département de Biologie, Faculté des Sciences, Université Dr. Moulay Tahar de Saida, BP 138 cité ENNASR, 20000 \\ Saida, Algeria \\ Corresponding author: e-mail: moubarek.mebarki@univ-usto.dz
}

\begin{abstract}
Pericarps of Algerian Quercus ilex (Q. ilex) and Quercus suber (Q. suber) were used as copper adsorbents in artificially contaminated solutions. Exposing accessible lignocellulosic binding sites enhanced adsorption. The lignocellulosic fractions of $Q$. suber and $Q$. ilex $(36.47 \pm 9.1$ and $47.66 \pm 9.3$, respectively) were characterized by FTIR before and after adsorption. The aim was to identify the functional groups adsorbing Cu(II). SEM/EDX determined lignocellulose surface morphology and composition. The amount of adsorbent-bound $\mathrm{Cu}(\mathrm{II})$ increased with initial [Cu(II)]. $\mathrm{Cu}(\mathrm{II})$ adsorption range was $23.59-48.06 \mathrm{mg} \cdot \mathrm{g}^{-1}$ for $Q$. Suber and $22.56-38.19 \mathrm{mg} \cdot \mathrm{g}^{-1}$ for $Q$. ilex when $[\mathrm{Cu}(\mathrm{II})]$ was $100-500 \mathrm{mg} \cdot \mathrm{L}^{-1}$. Adsorption isotherms and Langmuir and Freundlich models of the Q. suber and Q. ilex lignocellulosic fractions indicated natural $\mathrm{Cu}(\mathrm{II})$ adsorption capacities $\left(\mathrm{Q}_{\max }\right)$ of $53.76 \mathrm{mg} \cdot \mathrm{g}^{-1}$ and $36.06 \mathrm{mg} \cdot \mathrm{g}^{-1}$ and $\mathrm{KF}$ of $5.9 \mathrm{mg}^{-1} \mathrm{~g}^{-1}$ and $7.43 \mathrm{mg} \cdot \mathrm{g}^{-1}$, respectively.
\end{abstract}

Keywords: adsorption, $\mathrm{Cu}(\mathrm{II})$, lignocellulosic fraction, pericarp, Quercus sp..

\section{INTRODUCTION}

Water pollution by heavy metal cations is a major concern in developing countries including Algeria. Various techniques have been used to remove heavy metals from wastewater. These include adsorption ${ }^{1}$, coagulation ${ }^{2}$, advanced oxidation ${ }^{3}$, membrane separation ${ }^{4,5}$, foam flotation $^{6}$, precipitation $^{7}$, ozonation ${ }^{8}$, ion exchange ${ }^{9}$, filtration ${ }^{10}$, solvent extraction ${ }^{11}$, electrolysis ${ }^{12}$, synthetic oxidation ${ }^{13}$, liquid-fluid extraction ${ }^{14}$, and others. However, the main disadvantages of these methods are high operating costs and toxic waste production ${ }^{15}$. They also require expensive equipment and monitoring systems and are often energy demanding. Moreover, many of them are only marginal effective.

The utilization of agricultural and industrial waste products to purify wastewater has been extensively investigated $^{5,16,17,18,19,20}$. Biosorption is a cost-effective wastewater treatment tool. The materials are inexpensive, freely available and reusable. They produce minimal biological and chemical sludge ${ }^{21}$ and have high binding capacities for metalsions ${ }^{22}$. Therefore, they could be applied in novel and practical which would increase the value and utility of agricultural or forestry by-products ${ }^{23,24}$. Several economical and environmentally friendly waste materials have been considered as biosorbents. These include Eucalyptus sheathiana bark, Moringa or Sophora japonica residues, espresso coffee grounds, tea leaves, rice husks, tobacco stalks, white cedar stem, crab shells, mustard biomass, sawdust, corn silk, water lettuce dry biomass, herbaceous plants, pine bark, yeast, nutshells, citrus peels, and dead or living microorganisms $\mathrm{s}^{25,26,27,28}$.

Successful metal ion uptake by agricultural wastes depends upon lignocellulosic biomass with acidic functional groups such as phenolics and carboxylates on its surface. Heavy metals may form complexes with these groups by hydrogen ion substitution or electron pair donation ${ }^{28}$.Various unconventional, cost-effective adsorbents have been developed which are derived from natural materials and have high adsorption capacities. Adsorption has been improved by increasing the number of accessible carboxylate groups ${ }^{29,30,31}$ via covalent grafting of aminated oligogalacturonans ${ }^{32}$. However, the practicality of these methods is limited by the use of reactive toxic substances and/or organic solvents, costly equipment, and long protocols ${ }^{33}$. Therefore, they have no real advantages over conventional methods.

Copper is used extensively in electroplating, metallurgy, mechanical assembly, plumbing, construction, electrical wiring, and other industries. Copper-containing wastewater effluents are generated by copper mining, the electronic and electrical industries, computer heat sink production, ceramic glazing, glass coloring, and copper-based fungicide application. The World Health Organisation (WHO) recommends a drinking water threshold of $2.0 \mathrm{mg} \cdot \mathrm{L}^{-1}$ for copper ${ }^{34}$. Excessive copper may damage the liver and kidneys and cause anemia and reproductive/developmental toxicity. Therefore, the copper content in drinking water must be reduced to an acceptable level to ensure copper homeostasis in the human body ${ }^{35}$.

To the best of our knowledge, the present study is the first to test lignocellulosic fractions isolated from the acorn pericarps of $Q$. ilex and $Q$. suber as copper biosorbents. The pericarp is a waste product derived from acorn consumption and processing. Here, the $\mathrm{Cu}(\mathrm{II})$ ion adsorption capacities of the lignocellulosic fractions derived from the aforementioned oak tree species were compared. This paper proposes a new method of enhancing heavy metal adsorption using the accessible binding sites of the lignocellulosic fractions of plant cell walls. 


\section{EXPERIMENTAL}

\section{Plant material}

Acorns were harvested from $Q$. suber and $Q$. ilex. These oak tree species are indigenous to north-western Algeria. Q. ilex acorns were collected from the Saida region $\left(34^{\circ} 48^{\prime} 45.5^{\prime \prime} \mathrm{N}, 0^{\circ} 09^{\prime} 43.5^{\prime \prime} \mathrm{E}\right)$ and $Q$. suber acorns were sampled in the Oran region $\left(35^{\circ} 38^{\prime} 20.3^{\prime \prime} \mathrm{N} ; 0^{\circ} 50^{\prime} 22.6^{\prime \prime} \mathrm{W}\right)$ in December 2016. The acorns were cleaned and their pericarps were manually detached, dried in a ventilated oven at $40^{\circ} \mathrm{C}$, milled (particle size $<200 \mu \mathrm{m}$ ), and stored in desiccators at room temperature.

\section{Adsorbent isolation and preparation}

The lignocellulosic fractions were isolated from the pericarps in triplicate according to the methods of Bailey ${ }^{36}$ and Carpita ${ }^{37}$. The milled pericarp powder was continuously stirred in $80 \% \mathrm{v} / \mathrm{v}$ ethanol at $90^{\circ} \mathrm{C}$ for $20 \mathrm{~min}$ to extract the cell wall residues (cellulose, hemicelluloses, pectin, and lignin). The pectin was removed by mixing the extract with $\mathrm{H}_{2} \mathrm{O}$ at $100^{\circ} \mathrm{C}$ for $20 \mathrm{~min}$ followed by $1 \%$ $\mathrm{w} / \mathrm{v}$ ammonium oxalate at $85^{\circ} \mathrm{C}$ for $2 \mathrm{~h}$. The hemicelluloses were removed from the depectinated residue with a mixture of sodium hydroxide $(\mathrm{NaOH})$ and potassium hydroxide $(\mathrm{KOH})(4.3 \mathrm{M})$ at $22^{\circ} \mathrm{C}$ for $24 \mathrm{~h}$. The final remnant was the lignocellulosic fraction.

\section{Batch adsorption experiments}

$\mathrm{Cu}$ (II)solutions were prepared by dissolving cupric sulphate pentahydrate $\left(\mathrm{CuSO}_{4} \cdot 5 \mathrm{H}_{2} \mathrm{O}\right)$ in double-distilled water. In $100 \mathrm{~mL}$ flasks, $0.1 \mathrm{~g}$ lots of the lignocellulosic fraction were mixed with $50 \mathrm{~mL}$ copper sulphate solution ranging in initial concentration from $100-500 \mathrm{mg} \cdot \mathrm{L}^{-1}$ (pH 5). The flasks were placed on a mechanical agitator and shaken at $250 \mathrm{rpm}$. After $2 \mathrm{~h}$ equilibration at room temperature, the $\mathrm{Cu}$ (II) ion concentrations were determined by colorimetry for each flask ${ }^{38}$. Briefly, one volume of ammonium hydroxide $\left(\mathrm{NH}_{4} \mathrm{OH}\right)$ was mixed with four volumes of the adsorbed copper sulphate solutions, forming a blue complex. Absorbances of these solutions were measured at $620 \mathrm{~nm}$ in a $6715 \mathrm{UV} /$ Visible Jenway spectrophotometer (Cole-Parmer, Staffordshire, UK).

Adsorption capacity and \% copper removal were calculated using Eqs. 1 and 2, respectively ${ }^{39}$.

$\mathrm{Qe}=\frac{(C i-C e) V}{W}$

$\% \mathrm{RE}=\frac{C i-C e}{C i} \times 100$

where $\mathrm{Qe}$ is the equilibrium adsorption capacity per gram dry weight of the lignocellulosic fraction $\left(\mathrm{mg} \cdot \mathrm{g}^{-1}\right), \mathrm{V}$ is the volume of the $\mathrm{Cu}(\mathrm{II})$ solution (L), $\mathrm{Ci}$ and $\mathrm{Ce}$ are the initial and final $\mathrm{Cu}$ (II) concentrations after adsorption $\left(\mathrm{mg} \cdot \mathrm{L}^{-1}\right)$, respectively, and $\mathrm{W}$ is the dry weight in grams of the lignocellulosic fraction.

\section{CHARACTERIZATION}

The lignocellulosic fraction was characterized by Fourier transform infrared spectroscopy (FTIR) and scanning electron microscopy with energy-dispersive $\mathrm{X}$ -ray spectroscopy (SEM/EDX).
The lignocellulosic fractions of the pericarps were pelletized with potassium bromide $(\mathrm{KBr})$. One-milligram samples were diluted with $100 \mathrm{mg} \mathrm{KBr}$ before and after adsorption to identify the functional groups involved. The FTIR spectra were evaluated by FTIR spectrophotometry (400-4.000 $\mathrm{cm}^{-1} ; 4 \mathrm{~cm}^{-1}$ resolution; 32 accumulations) (Cary 600; Agilent Technologies, Santa Clara, CA, USA).

Adsorbent surface morphology and elemental composition were determined by scanning electron microscopy (SEM) and energy-dispersive X-ray spectroscopy (EDX).

The lignocellulosic fractions were examined at $250 \times$ and $10.000 \times$ under a JSM-6610 SEM (JEOL Ltd., Akishima, Tokyo, Japan). Images were photographed under the secondary electron detector at an acceleration voltage of $20 \mathrm{kV}$.

Adsorbents were subjected to EDX analysis (EX-9430054L1Q; JEOL Ltd., Akishima, Tokyo, Japan) before and after $\mathrm{Cu}(\mathrm{II})$ loading. Adsorption of copper cation onto the surfaces of the lignocellulosic fractions was verified.

\section{RESULTS AND DISCUSSION}

\section{Yield of lignocellulosic fraction}

The net lignocellulosic fraction yields are shown in Table 1 . The cell wall residue constituted $79.45 \pm 1.0 \%$ and $86.09 \pm 1.4 \%$ of the dry mass of the $Q$. suber and $Q$. ilex pericarps, respectively. The lignocellulosic fraction constituted $36.47 \pm 9.1 \%$ and $47.66 \pm 9.3 \%$ of the cell wall residues from the pericarps of $Q$. suber and $Q$. ilex, respectively.

Table 1. Lignocellulosic yields from pericarps of $Q$. suber and Q. ilex

\begin{tabular}{|l|c|c|}
\hline & Cell wall residue $^{*}$ & Lignocellulosic fraction $^{* *}$ \\
\hline Q. suber & $79.45 \pm 1.0$ & $36.47 \pm 9.1$ \\
\hline Q. ilex & $86.09 \pm 1.4$ & $47.66 \pm 9.3$ \\
\hline
\end{tabular}

${ }^{*}$ Percentage of the initial $15 \mathrm{~g}$ of acorn pericarp powder (dry weight); ${ }^{* *}$ Weight $\%$ of cell wall residue

Q. ilex pericarps contained significantly more cell wall residue and lignocellulosic fraction than those of $Q$. suber. Genetic and environmental factors account for these differences. Saïda is a high plateau whereas Oran is a seacoast area. Moreover, geographic location, soil salinity, light intensity, hydration, plant species, harvest timing, and life cycle stage also influence the distribution and abundance of various compounds in plants ${ }^{\mathbf{4 0}, 41,42}$.

\section{Batch adsorption studies}

The aim of this study was to determine the influence of the initial $\mathrm{Cu}$ (II) ion concentration on the adsorption capacities of lignocellulosic fractions derived from $\mathrm{Qu}$ ercus ilex and Quercus suber pericarps. Data are shown in Table 2 and in Figs. 1 and 2.

Figures 1 and 2 show that the quantity of $\mathrm{Cu}(\mathrm{II})$ adsorbed by the lignocellulosic fraction increased with initial $\mathrm{Cu}(\mathrm{II})$ concentration. From $100-400 \mathrm{mg} \cdot \mathrm{L}^{-1} \mathrm{Cu}(\mathrm{II})$, the adsorption capacities Qe increased from 23.59-48.06 $\mathrm{mg} \cdot \mathrm{g}^{-1}$ and from $22.56-38.19 \mathrm{mg} \cdot \mathrm{g}^{-1}$ for $Q$. suber and $Q$. ilex, respectively.

The number of copper ions in solution and the copper absorption capacity increased with copper solution concentration. On the other hand, the \% copper cation 
Table 2. Copper adsorption by lignocellulosic fractions of $Q$. suber and $Q$. ilex pericarps

\begin{tabular}{|c|c|c|c|c|}
\cline { 2 - 5 } \multicolumn{1}{c|}{} & \multicolumn{2}{c|}{ Q. suber } & \multicolumn{2}{c|}{ Q. ilex } \\
\hline $\mathrm{Ci}[\mathrm{mg} / \mathrm{L}]$ & Qe $[\mathrm{mg} / \mathrm{g}]$ & \%RE & 22.56 & \%RE \\
\hline 100 & 23.59 & 47.18 & 23.81 & 45.13 \\
\hline 200 & 27.50 & 27.50 & 28.81 & 23.81 \\
\hline 300 & 39.72 & 26.48 & 34.44 & 19.21 \\
\hline 400 & 38.06 & 19.03 & 38.19 & 17.22 \\
\hline 500 & 48.06 & 19.22 & 15.27 \\
\hline
\end{tabular}

$\mathrm{Ci}$ : initial concentrations of $\mathrm{Cu}(\mathrm{II})(\mathrm{mg} / \mathrm{L})$; Qe: equilibrium adsorption capacity $(\mathrm{mg} / \mathrm{g})$; \%RE: percentage removal

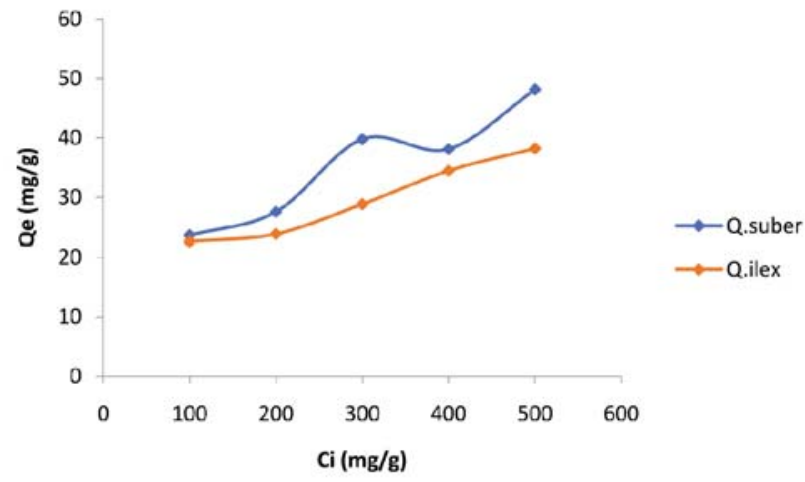

Figure 1. Effect of the initial $\mathrm{Cu}(\mathrm{II})$ concentration on lignocellulosic fraction adsorption capacities of $Q$. suber and $Q$. ilex pericarps

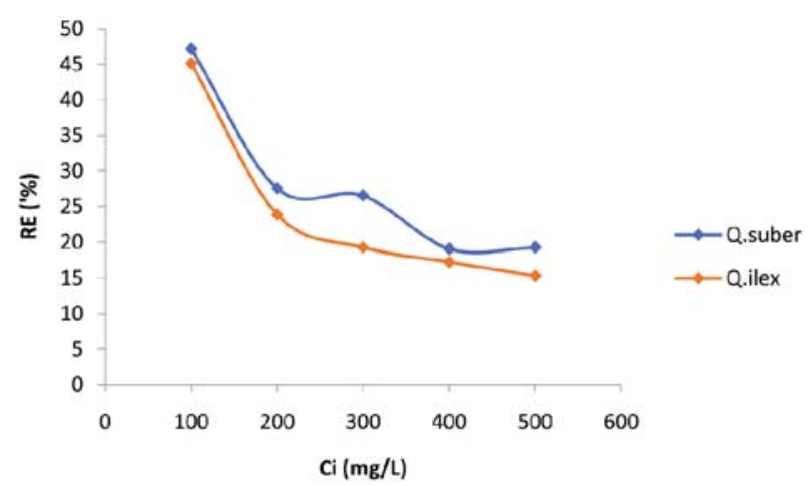

Figure 2. Effect of the initial $\mathrm{Cu}(\mathrm{II})$ concentration on the \% adsorption removal by the lignocellulosic fractions of $Q$. suber and $Q$. ilex pericarps

removal by adsorption decreased with initial copper solution concentration from $47.18-19.22 \%$ and from $45.13-15.27 \%$ for $Q$. suber and $Q$. ilex, respectively.

The copper cation adsorption capacity of the lignocellulosic fraction prepared in the present study was higher than those reported for other biosorbents cited in the literature (Table 3).

Table 3. Copper retention capacities of selected biosorbents

\begin{tabular}{|l|c|c|}
\hline Biosorbent & $\begin{array}{l}\mathrm{Q}_{\max } \\
{[\mathrm{mg} / \mathrm{g}]}\end{array}$ & References \\
\hline $\begin{array}{l}\text { Tomato waste (Solanum } \\
\text { lycopersicum) }\end{array}$ & 34.48 & 43 \\
\hline Corn stalk & 20.8 & 44 \\
\hline Sugar beet pulp & 16.14 & 45 \\
\hline $\begin{array}{l}\text { Single-celled green algae Chlorella } \\
\text { pyrenoidosa }\end{array}$ & 12.58 & 46 \\
\hline Fungus Penicillium ochrochloron & 8.98 & 47 \\
\hline Sorghum stem Sorghum bicolor & 7.93 & \\
\hline Banana stem Musa acuminata & 6.49 & 48 \\
\hline $\begin{array}{l}\text { Casuarinas fruit Casuarina } \\
\text { equisetifolia }\end{array}$ & 4.54 & 49 \\
\hline Pinion shell & 4.29 & 49 \\
\hline
\end{tabular}

\section{FTIR analyses}

The FTIR spectrum of the lignocellulosic fraction of $Q$. suber before $\mathrm{Cu}(\mathrm{II})$ adsorption showed a peak at $891 \mathrm{~cm}^{-1}$ which corresponds to a C-H deformation in cellulose. Another peak at $1.062 \mathrm{~cm}^{-1}$ represented a C-O stretch in polysaccharides ${ }^{50}$. A band at $\sim 1.389$ $\mathrm{cm}^{-1}$ is associated with a C-H deformation in polysaccharides and a $\mathrm{C}_{\text {aryl }}-\mathrm{O}$ vibration in syringyl derivatives ${ }^{51}$. Peaks at $1.507 \mathrm{~cm}^{-1}$ and $1.595 \mathrm{~cm}^{-1}$ were related to the aromatic skeleton of lignin. The band at $\sim 1.647 \mathrm{~cm}^{-1}$ is characteristic of $\mathrm{C}=\mathrm{O}$ stretching in carboxylates. The bands observed at $2.891 \mathrm{~cm}^{-1}$ correlate with symmetric $\mathrm{C}-\mathrm{H}$ stretching and $\mathrm{CH}_{2}$ group vibration. The bands at $3.318 \mathrm{~cm}^{-1}$ are ascribed to the hydrogen-bonded $\mathrm{O}-\mathrm{H}$ groups of cellulose and lignin.

After $\mathrm{Cu}$ (II) adsorption, the peaks in the FTIR spectrum of the lignocellulosic fraction shifted from 1.389 $\mathrm{cm}^{-1}$ to $1.378 \mathrm{~cm}^{-1}, 1.647 \mathrm{~cm}^{-1}$ to $1.645 \mathrm{~cm}^{-1}, 2.361 \mathrm{~cm}^{-1}$ to $2.359 \mathrm{~cm}^{-1}, 2.891 \mathrm{~cm}^{-1}$ to $2.899 \mathrm{~cm}^{-1}$, and $3.318 \mathrm{~cm}^{-1}$ to $3.309 \mathrm{~cm}^{-1}$. The band at $1.595 \mathrm{~cm}^{-1}$ disappeared (Figure 3). Therefore, the $\mathrm{C}-\mathrm{H}, \mathrm{C}=\mathrm{O}$, and $\mathrm{O}-\mathrm{H}$ groups in the lignocellulosic fractions participated in $\mathrm{Cu}(\mathrm{II})$ adsorption.



Figure 3. FTIR spectra of the lignocellulosic fraction (LCF) of $Q$. suber before and after $\mathrm{Cu}(\mathrm{II})$ adsorption

The lignocellulosic fraction of $Q$. ilex before copper adsorption produced spectral peaks at $671,895,1.059$, $\sim 1.375,1.594,1.645,1.783$ and $3.334 \mathrm{~cm}^{-1}$. These peaks are associated with $\mathrm{C}-\mathrm{OH}$ out-of-plane bending, $\mathrm{C}-\mathrm{H}$ bending, C-O-C asymmetrical stretching, $\mathrm{CH}$ in-plane bending, $\mathrm{C}=\mathrm{C}$ aromatic symmetrical stretching, $\mathrm{C}=\mathrm{O}$ stretching vibration, and hydroxyl stretching, respectively.

Figure 4 shows the changes in the peaks from 1.783 $\mathrm{cm}^{-1}$ to $1.792 \mathrm{~cm}^{-1}, 2.901 \mathrm{~cm}^{-1}$ to $2.891 \mathrm{~cm}^{-1}$ and 3.334 $\mathrm{cm}^{-1}$ to $3.320 \mathrm{~cm}^{-1}$. These shifts confirm that the $\mathrm{C}=\mathrm{O}$, $\mathrm{C}-\mathrm{H}$, and $\mathrm{OH}$ functional groups participate in $\mathrm{Cu}(\mathrm{II})$ adsorption. 


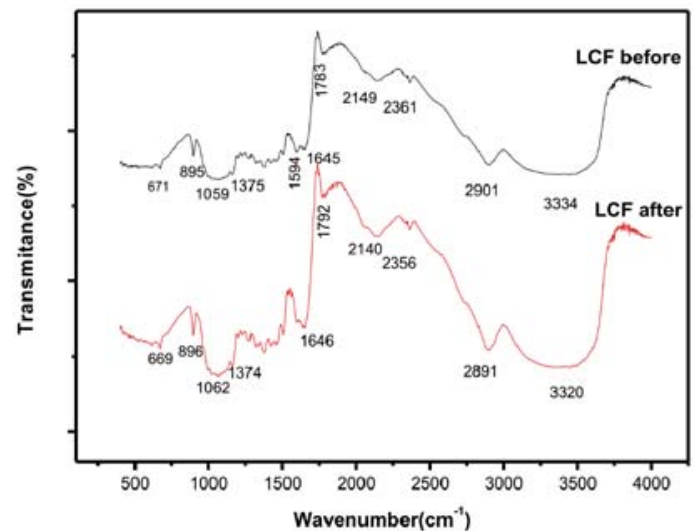

Figure 4. FTIR spectra of the lignocellulosic fraction (LCF) of $Q$. ilex before and after $\mathrm{Cu}(\mathrm{II})$ adsorption

\section{SEM and EDX analyses}

SEM and EDX confirmed that $\mathrm{Cu}(\mathrm{II})$ permeated the pores of the lignocellulosic fractions (LCF).

Adsorbent surface morphology was examined by SEM. Figs. 5a and $6 \mathrm{c}$ show that the surfaces of the LCFs of $Q$. ilex and $Q$. suber before $\mathrm{Cu}(\mathrm{II})$ adsorption were porous and rough and consisted of lignin-coated cellulosic fibers. In contrast, the pores on the LCFs after $\mathrm{Cu}$ (II) adsorption appeared to be filled. Fig. 6d shows white dots on the surface of the lignocellulosic fraction of Quercus ilex following $\mathrm{Cu}(\mathrm{II})$ adsorption. These artefacts may have formed from reactions between lignocellulose and copper cations ${ }^{\mathbf{5 2}}$.
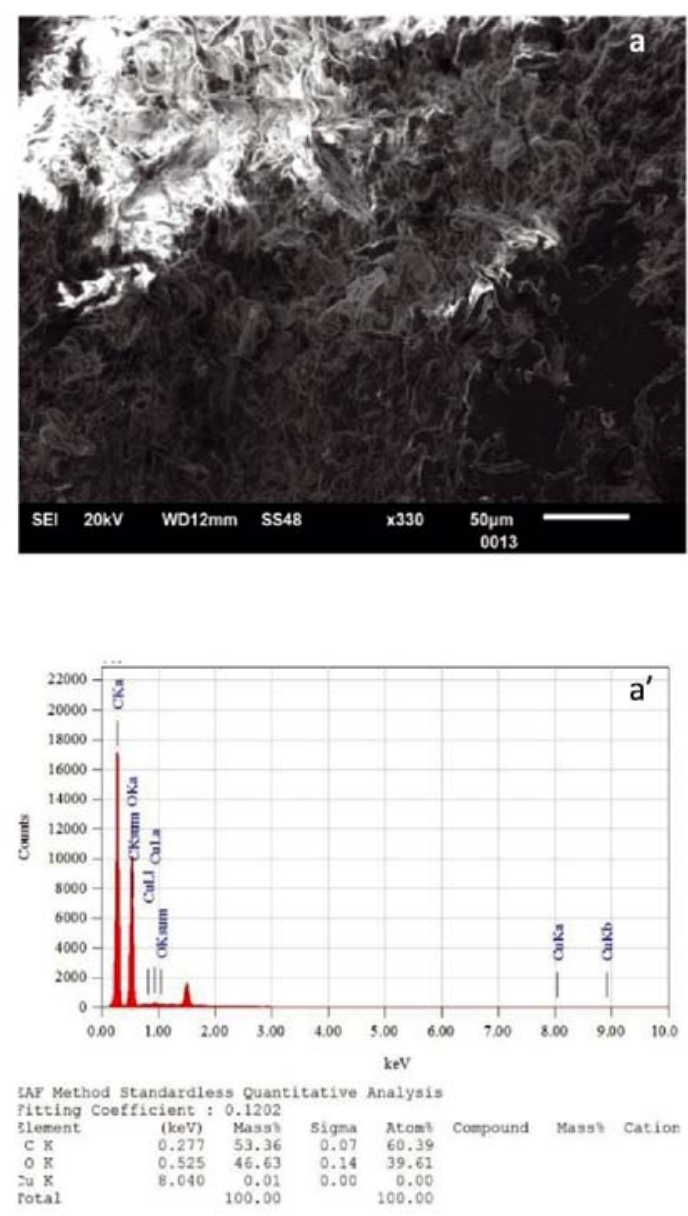

The EDX spectra revealed the surface atomic distribution and elemental composition of the lignocellulosic fraction ( $\mathrm{LCF}$ ). The $\mathrm{Cu}(\mathrm{II})$ peak appeared at $8 \mathrm{KeV}$. The copper identified in the pre-adsorption fractions probably originated from the soil in which the oak trees grew ${ }^{\mathbf{5 2}}$. After adsorption, the relative $\%$ copper mass increased from $0.01-0.08 \%$ and from $0.08-0.09 \%$ in the LCFs of $Q$. ilex and $Q$. suber, respectively ${ }^{\mathbf{5 3}}$.

$\mathrm{C}, \mathrm{O}, \mathrm{Na}$, and $\mathrm{K}$ were also detected on the adsorbent surfaces. The $\mathrm{Na}$ and $\mathrm{K}$ found in the lignocellulosic fraction (Fig. 5b')were derived from the sodium hydroxide $(\mathrm{NaOH})$ and potassium hydroxide $(\mathrm{KOH})$ used to remove the hemicelluloses from the pericarp.

\section{Langmuir isotherm model}

The Langmuir adsorption model ${ }^{54}$ disclosed that monolayer adsorption occurs at dynamic homogeneous sites on the adsorbent surfaces. However, the particles adsorbed there did not interact.

$\mathrm{No} \mathrm{Cu}(\mathrm{II})$ particle transmigration was detected on the adsorbent surface. The Langmuir isotherm equation(3) and its linearization (4) are as follows:

$Q e=\frac{\mathrm{Qmax} \cdot \mathrm{K} \cdot \mathrm{Ce}}{1+\mathrm{K} \cdot \mathrm{Ce}}$

$\frac{1}{\mathrm{Qe}}=\frac{1}{Q \max }+\frac{1}{K \cdot Q \max } \cdot \frac{1}{\mathrm{Ce}}$

where Qe $\left(\mathrm{mg} \cdot \mathrm{g}^{-1}\right)$ is the quantity of $\mathrm{Cu}(\mathrm{II})$ adsorbed at equilibrium, $\mathrm{Q}_{\max }$ is the maximum adsorption capacity
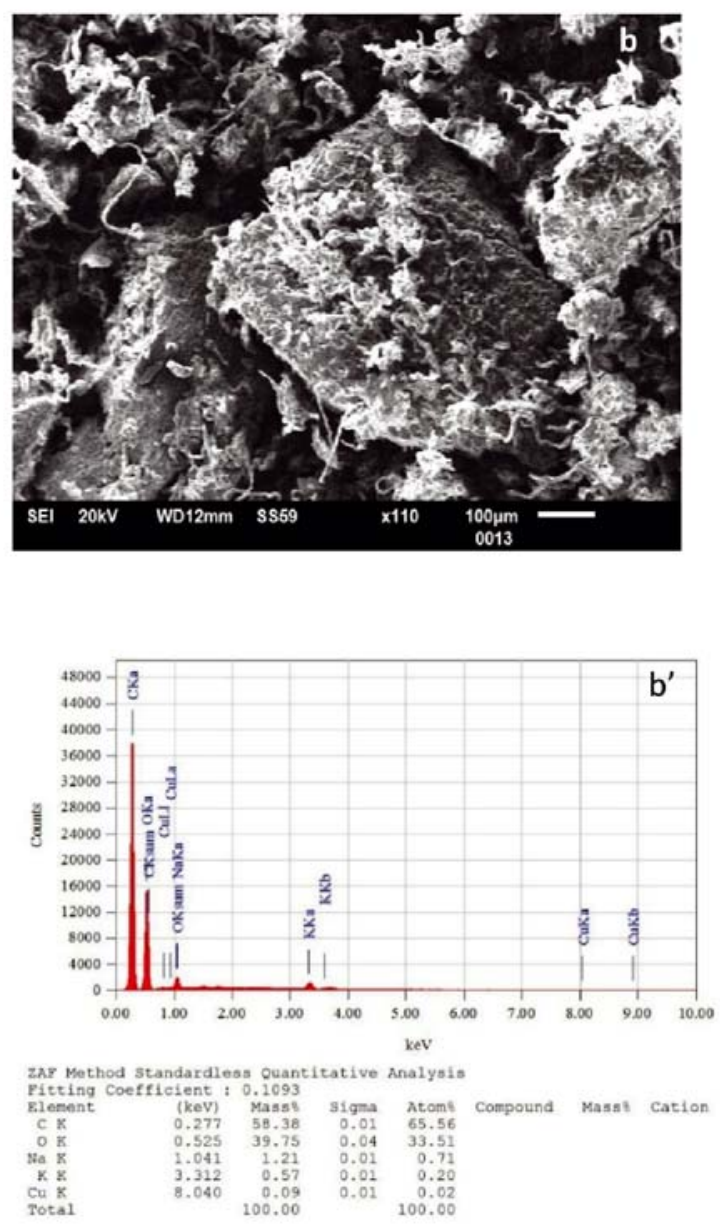

Figure 5. SEM and EDX of the lignocellulosic fraction of $Q$. ilex before (a, a') and after (b, b') copper adsorption 

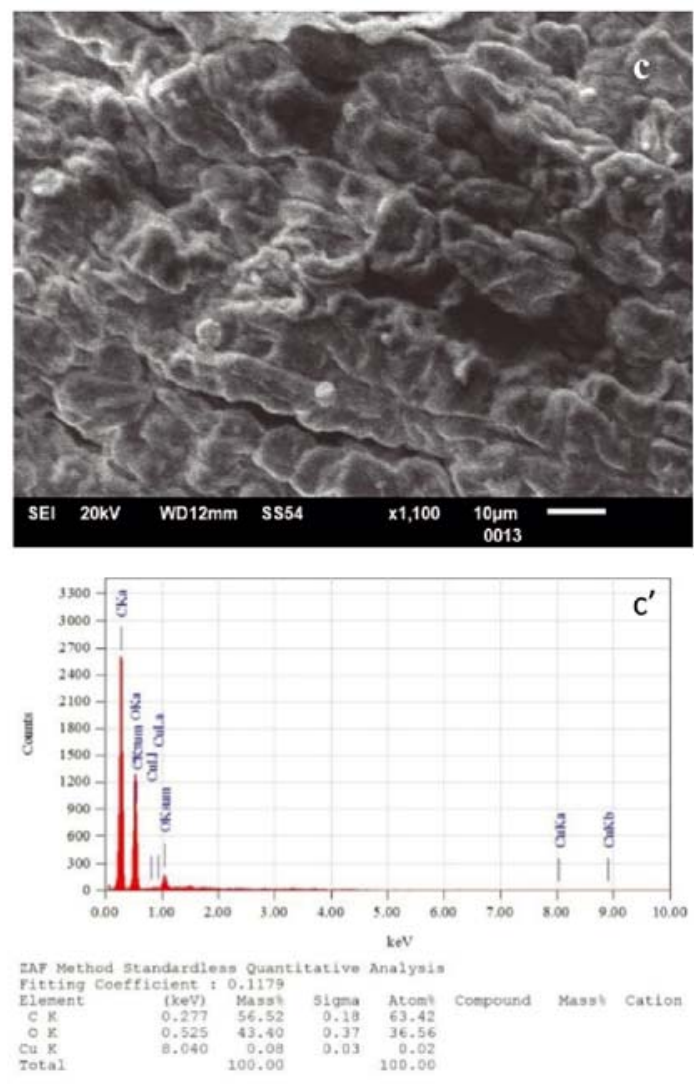
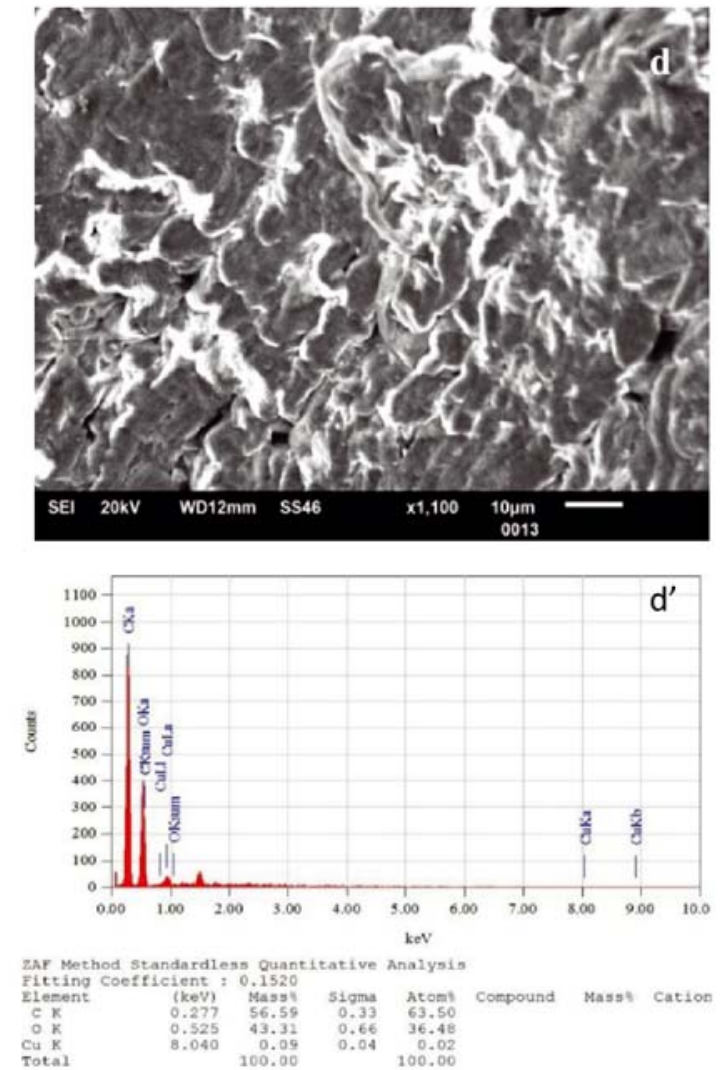

Figure 6. SEM and EDX of the lignocellulosic fraction of $Q$. suber before (c, c') and after (d, d') copper adsorption

of the adsorbent, $\mathrm{Ce}\left(\mathrm{mg} \cdot \mathrm{L}^{-1}\right)$ is the concentration of the copper solution and $\mathrm{K}_{\mathrm{L}}$ is the Langmuir constant.

The Langmuir isotherm may be characterized by a dimensionless constant separation factor (RL) defined as:

$$
R L=\frac{1}{1+(\mathrm{Qmax} \cdot \mathrm{K}) \cdot \mathrm{C} 0}
$$

where $\left(R_{L}=1\right)$ is a linear isotherm, $\left(0<R_{L}<1\right)$ is a favorable isotherm, $\left(R_{L}>1\right)$ is an unfavorable isotherm and $\left(R_{L}=0\right)$ is irreversible adsorption ${ }^{28}$.

The $\mathrm{R}_{\mathrm{L}}$ shown in Table 4 (0.004 and 0.005 for the LCFs of $Q$. ilex and $Q$. suber, respectively) indicate that these materials are suitable for $\mathrm{Cu}(\mathrm{II})$ adsorption. Nevertheless, the model presented in Figs. 7 and 8 shows a low degree of linearization with the adsorption data $\left(\mathrm{R}^{2}=0.756\right.$ for $Q$. ilex; $\mathrm{R}^{2}=0.8675$ for $Q$. suber). Therefore, $\mathrm{Cu}(\mathrm{II})$ adsorption does not reach saturation on either LCF. This finding aligned with the adsorption isotherms presented in Fig. 9. Moreover, $\mathrm{K}_{\mathrm{L}}$ was comparatively high for the Q. ilex adsorbent. Thus, it can retain $\mathrm{Cu}(\mathrm{II})$ even when the residual $\mathrm{Cu}(\mathrm{II})$ concentration is low. The lignocellulosic fraction of $Q$. suber had a $\mathrm{Q}_{\max }$ of $53.76 \mathrm{mg} \cdot \mathrm{g}^{-1}$ which surpasses the values recently reported for copper adsorption (Table 3 ).

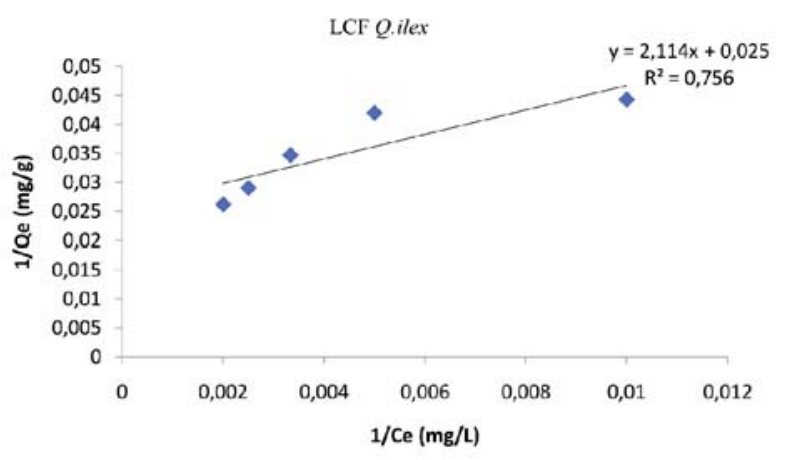

Figure 7. Langmuir isotherm model of copper (II) biosorption onto the lignocellulosic fraction of $Q$. ilex

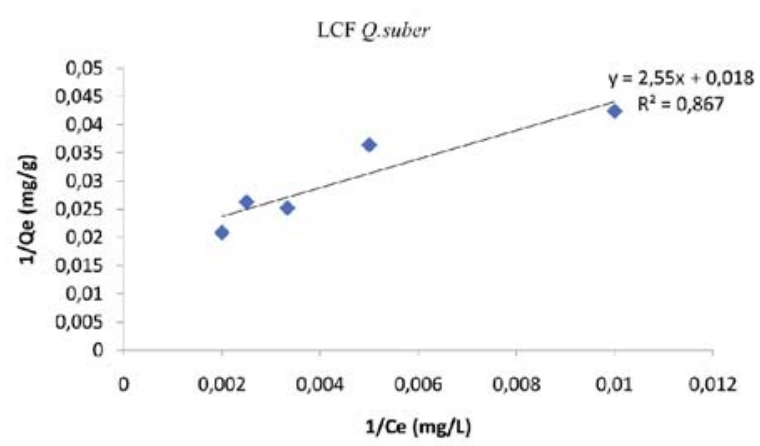

Figure 8. Langmuir isotherm model of copper (II) biosorption onto the lignocellulosic fraction of $Q$. suber

Table 4. Langmuir and Freundlich parameters for copper adsorption by lignocellulosic fractions (LCF) of $Q$. ilex and $Q$. suber pericarps

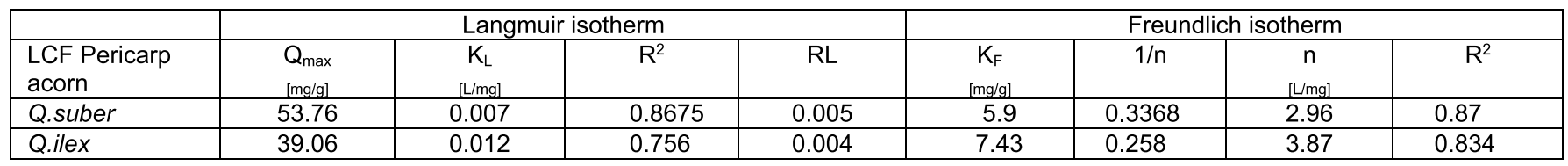




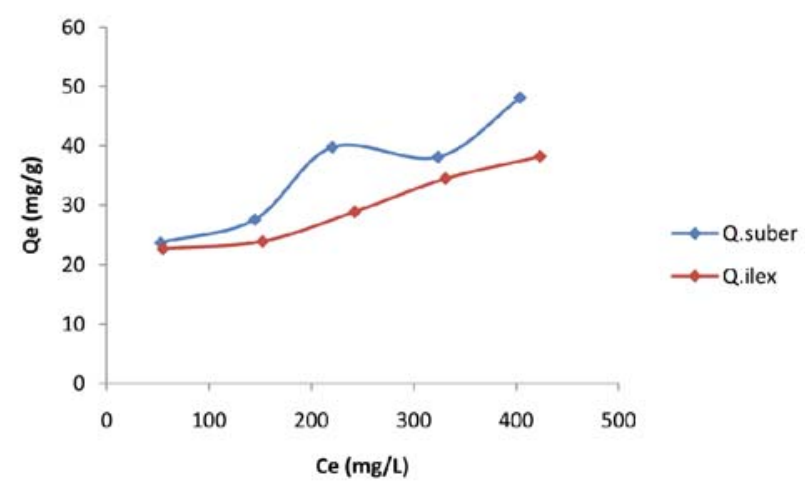

Figure 9. Adsorption isotherm of copper (II) biosorption onto the lignocellulosic fraction of $Q$. suber and $Q$. ilex

\section{Freundlich isotherm model}

The Freundlich isotherm describes adsorption on heterogeneous surfaces ${ }^{55}$ and is defined by the following equation:

$Q e=K_{F} \cdot C e^{1 / \mathrm{n}}$

where Qe $\left(\mathrm{mg} \cdot \mathrm{g}^{-1}\right)$ is the quantity of $\mathrm{Cu}(\mathrm{II})$ adsorbed at equilibrium, $\mathrm{Ce}\left(\mathrm{mg} \cdot \mathrm{L}^{-1}\right)$ is copper concentration in the solution at equilibrium and $\mathrm{K}_{\mathrm{F}}\left(\mathrm{mg} \cdot \mathrm{g}^{-1}\right)$ and $\mathrm{n}\left(\mathrm{g} \cdot \mathrm{L}^{-1}\right)$ are indices of adsorption capacity and intensity, respective$1 y^{56} . K_{F}$ and $n$ can be interpolated form a linear plot of $\log$ Qe vs. $\log$ Ce. as follows:

$\log Q e=\log K_{F}+\frac{1}{\mathrm{n}} \cdot \log C e$

A high $\mathrm{K}_{\mathrm{F}}$ is indicative of high adsorption capacity. The LCF of $Q$. ilex had $\mathrm{K}_{\mathrm{F}}=7.43 \mathrm{mg} \cdot \mathrm{g}^{-1}$ whilst that of Q. suber was only $5.9 \mathrm{mg} \cdot \mathrm{g}^{-1}$ (Table 4; Figs. 10 and 11). The factor $1 / \mathrm{n}$ estimates the adsorption intensity or surface heterogeneity. A value of $1 / \mathrm{n}$ approaching zero indicates heterogeneity of the adsorbent ${ }^{57}$. The LCF of $Q$. ilex was more heterogeneous than that of $Q$. suber. The adsorption capacity is favorable when $0<1 / \mathrm{n}<1$. Based on this criterion, the adsorption capacities of both $Q$. ilex and $Q$. suber LCF were favorable. Linearization with the adsorption data $\left(\mathrm{R}^{2}=0.834\right.$ for $Q$. ilex and $\left(\mathrm{R}^{2}=0.87\right.$ for $Q$. suber $)$ suggested that the Freundlich isotherm model more accurately described the copper (II) ion biosorption kinetics than the Langmuir model.

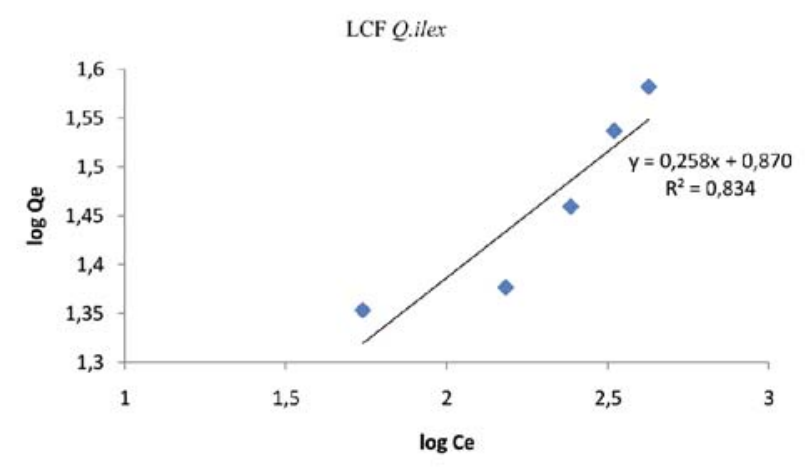

Figure 10. Freundlich isotherm model of copper (II) biosorption onto the lignocellulosic fraction of $Q$. ilex

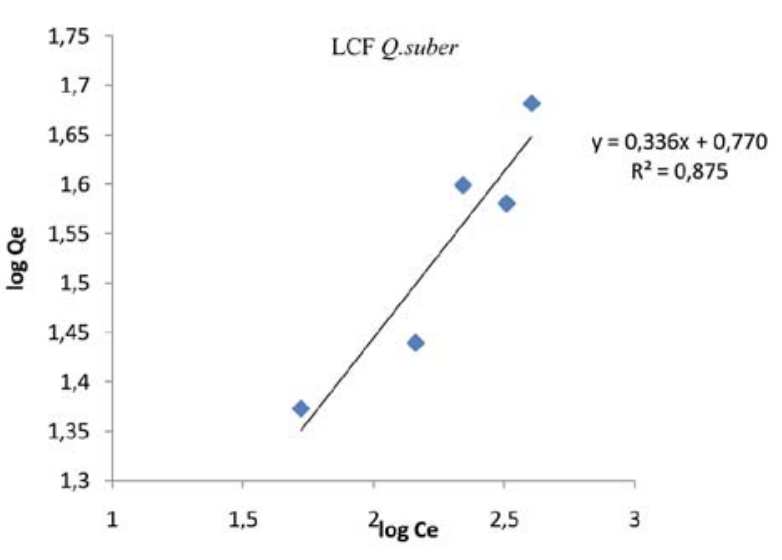

Figure 11. Freundlich isotherm model of copper (II) biosorption onto the lignocellulosic fraction of $Q$. suber

\section{CONCLUSION}

The identification of new adsorbents and the evaluation of their functional properties have become research priorities. Here, we studied the copper adsorption capacity of the lignocellulosic fractions of the pericarps from the acorns of the oak tree species Quercus suber and Quercus ilex. These species are widely distributed across the Mediterranean coast, particularly in north-western Algeria. The equilibrium adsorption capacity of the lignocellulosic fraction could be optimized by increasing the initial copper concentration. A Langmuir isothermal model adequately described the adsorption process. FTIR and SEM/EDX analyses indicated that adsorption occurs specifically through physicochemical interactions between the lignocellulosic fraction and the metal cations. The lignocellulosic fraction of acorn pericarps may be very promising as an adsorbent effectively removing copper cations from wastewater.

\section{ACKNOWLEDGMENTS}

The authors thank Sahraoui Toufik of the Laboratoire de Microscopie Electronique et des Sciences des Matériaux (LMESM) USTO M-B for performing the SEM/EDX analyses. This study was funded by the University of Sciences and Technology Mohamed Boudiaf, Oran, Algeria.

\section{LITERATURE CITED}

1. Afroze, S. \& Sen, T.K. (2018). A review on heavy metal ions and dye adsorption from water by agricultural solid waste adsorbents. Water Air Soil Pollut. 229, 225. DOI: 10.1007/ s11270-018-3869-z.

2. Amuda, O.S., Amoo, I.A., Ipinmoroti, K.O. \& Ajayi, O.O.(2006). Coagulation/flocculation process in the removal of trace metals present in industrial wastewater. J. Appl. Sci. Environ. Manage.10(3), 159-162. DOI: 10.4314/jasem.v10i3.17339.

3. Wang, J.L. \& Xu, L.J. (2012). Advanced oxidation processes for wastewater treatment: formation of hydroxyl radical and application. Crit. Rev. Environ. Sci. Technol. 42, 251-325. DOI: $10.1080 / 10643389.2010 .507698$.

4. Rivas, B.L. \& Palencia, M. (2011). Removal-concentration of pollutant metal-ions by water-soluble polymers in conjunction with double emulsion systems: A new hybrid method of membrane-based separation. Sep. Purif. Technol. 81(3), 435-443. DOI: 10.1016/j.seppur.2011.08.021.

5. Saleh, T.A. \& Gupta, V.K. (2014). Processing methods, characteristics and adsorption behavior of tire derived car- 
bons: A review. Adv. Colloid. Interface Sci. 211, 93-101. DOI: 10.1016/j.cis.2014.06.006.

6. Rubio, J., Souza, M.L. \& Smith, R.W. (2002). Overview of flotation as a wastewater treatment technique. Miner. Eng. 15(3), 139-155. DOI: 10.1016/S0892-6875(01)00216-3.

7. Agwaramgbo, L., Magee, N., Nunez, S. \& Mitt, K. (2013). Biosorption and chemical precipitation of lead using biomaterials, molecular sieves, and chlorides, carbonates, and sulfates of Na \& Ca. J. Environ. Prot. 4(11), 1251-1257. DOI: 10.4236/ jep.2013.411145.

8. Gähr, F., Hermanutz, F. \& Oppermann, W. (1994). Ozonation-an important technique to comply with new German laws for textile wastewater treatment. Water Sci. Technol. 30(3), 255-263. DOI: 10.2166/wst.1994.0115.

9. Abdel-Aziz, M.H., Nirdosh, I. \& Sedahmed, G.H. (2013). Ion-exchange-assisted electrochemical removal of heavy metals from dilute solutions in a stirred-tank electrochemical reactor: a mass-transfer study. Ind. Eng. Chem. Res. 52(33), 11655-11662. DOI: 10.1021/ie400548w.

10. Dean, J.G., Bosqui, F.L. \& Lanouette, K.H. (1972). Removing heavy metals from waste water. Environ. Sci. Technol. 6(6), 518-522. DOI: 10.1021/es60065a006.

11. Lin, S.H. \& Juang, R.S. (2002). Removal of free and chelated $\mathrm{Cu}$ (II) ions from water by a nondispersive solvent extraction process. Water Res. 36, 3611-3619. DOI: 10.1016/ S0043-1354(02)00074-X.

12. Tao, H.C., Lei, T., Shi, G., Sun, X.N., Wei, X.Y., Zhang, L.J. \& Wu, W.M.(2014). Removal of heavy metals from fly ash leachate using combined bioelectrochemical systems and electrolysis. J. Hazard. Mater. 264, 1-7. DOI: 10.1016/j. jhazmat.2013.10.057.

13. Sreeprasad, T.S., Maliyekkal, S. M., Lisha, K.P. \& Pradeep, T. (2011). Reduced graphene oxide-metal/metal oxide composites: facile synthesis and application in water purification. J. Hazard. Mater. 186(1), 921-931. DOI: 10.1016/j. jhazmat.2010.11.100.

14. Nielsen, P.B., Christensen, T.C. \& Vendrup, M. (1997). Continuous removal of heavy metals from FGD wastewater in a fluidised bed without sludge generation. Water Sci. Technol. 36(2-3), 391-397. DOI: 10.1016/S0273-1223(97)00413-7.

15. Ahluwalia, S.S. \& Dinesh, G. (2007). Microbial and plant derived biomass for removal of heavy metals from wastewater. Biores.Technol. 98(12), 2243-2257. DOI: 10.1016/j. biortech.2005.12.006.

16. Bailey, S.E., Olin, T.J., Bricka, R.M. \& Adrian, D. D. (1999). A review of potentially low-cost sorbents for heavy metals. Water Res. 33 (11),2469-2479. DOI: 10.1016/S00431354(98)00475-8.

17. Mohan, D., Sarswat, A., Ok, Y.S., \& Pittman, C.U. (2014). Organic and inorganic contaminants removal from water with biochar, a renewable, low cost and sustainable adsorbent - a critical review. Biores. Technol. 160, 191-202. DOI: 10.1016/j.biortech.2014.01.120.

18. Vikrant, K., Giri, B.S., Raza, N., Roy, K., Kim, K.H., Rai, B.N., \& Singh, R.S. (2018). Recent advancements in bioremediation of dye: current status and challenges. Biores. Technol. 253, 355-367. DOI: 10.1016/j.biortech.2018.01.029.

19. Robati, D., Mirza, B., Rajabi, M., Moradi, O., Tyagi, I., Agarwal, S. \& Gupta, V.K., (2016). Removal of hazardous dyes-BR 12 and methyl orange using graphene oxide as an adsorbent from aqueous phase. Chem. Eng. J. 284, 687-697. DOI: 10.1016/j.cej.2015.08.131.

20. Gupta, V.K., Nayak, A., Agarwal, S. \& Tyagi, I. (2014). Potential of activated carbon from waste rubber tire for the adsorption of phenolics: effect of pre-treatment conditions. J. Colloid. Interface Sci. 417, 420-430. DOI: 10.1016/j. jcis.2013.11.067.

21. Barka, N., Abdennouri, M., El-Makhfouk, M. \& Qoursal S. (2013). Biosorption characteristics of cadmium and lead onto eco-friendly dried cactus (Opuntia ficus indica) clado- des. J. Environ. Chem. Eng. 1(3), 144-149. DOI: 10.1016/j. jece.2013.04.008.

22. Gupta, V.K. \& Rastogi, A. (2008). Biosorption of lead from aqueous solutions by green algae Spirogyraspecies: kinetics and equilibrium studies. J. Hazard. Mater. 2008;152(1), 407-414. DOI: 10.1016/j.jhazmat.2007.07.028.

23. Afroze, S. \& Sen, T.K. (2018). A review on heavy metal ions and dye adsorption from water by agricultural solid waste adsorbents.Water Air Soil Pollut. 229(7), 225. DOI: 10.1007/ s11270-018-3869-z.

24. Gupta, V.K. \& Saleh, T.A. (2013). Sorption of pollutants by porous carbon, carbon nanotubes and fullerene-an overview. Environ. Sci. Pollut. Res. 20(5), 2828-2843. DOI: 10.1007/s11356-013-1524-1.

25. Ahmaruzzaman, M. \& Gupta, V. K. (2011). Rice husk and its ash as low-cost adsorbents in water and wastewater treatment. Ind. Eng. Chem. Res. 50(24), 13589-13613. DOI: 10.1021/ie201477c.

26. Hao, X., Mohamad, O.A., Xie, P., Rensing, C. \& Wei, G. (2014). Removal of zinc from aqueous solution by metal resistant symbiotic bacterium Mesorhizobium amorphae. Separ. Sci. Technol. 49(3), 376-387. DOI: 10.1080/01496395.2013.843195.

27. Jakóbik-Kolon, A., Mitko, K. \& Bok-Badura, J. (2017). Zinc sorption studies on pectin-based biosorbents. Materials 10(7), 844. DOI: 10.3390/ma10070844.

28. Haroon, H., Gardazi, S.M.H., Butt, T.A., Pervez, A., Mahmood, Q. \& Bilal, M. (2017). Novel lignocellulosic wastes for comparative adsorption of $\mathrm{Cr}(\mathrm{VI})$ : equilibrium kinetics and thermodynamic studies. Pol. J. Chem. Technol. 19(2),6-15. DOI: 10.1515/pjct-2017-0021.

29. Marchetti, V., Clément, A., Gérardin, P. \& Loubinoux, B. (2000). Synthesis and use of esterified sawdusts bearing carboxyl group for removal of cadmium(II) from water.Wood Sci.Technol. 34(2), 167-173. DOI: 10.1007/s002260000040.

30. Hachem, K., Astier, C., Chaleix, V., Faugeron, C., Krausz, P., Kaid-Harche, M. \& Gloaguen, V. (2012). Optimization of lead and cadmium binding by oxidation of biosorbent polysaccharidic moieties. Water Air Soil Pollut. 223(7), 3877-3885. DOI: $10.1007 / \mathrm{s} 11270-012-1156-\mathrm{y}$.

31. Genevois, N., Villandier, N., Chaleix, V., Poli, E., Jauberty, L. \& Gloaguen, V. (2017). Removal of cesium ion from contaminated water: improvement of Douglas fir bark biosorption by a combination of nickel hexacyanoferrate impregnation and TEMPO oxidation. Ecol. Eng. 100, 186-193. DOI: 10.1016/j. ecoleng.2016.12.012.

32. Astier, C., Chaleix, V., Faugeron, C., Ropartz, D., Gloaguen, V. \& Krausz, P. (2010). Grafting of aminated oligogalacturonans onto Douglas fir barks. a new route for the enhancement of their lead(II) binding capacities. J. Hazard. Mater. 182(1), 279-285. DOI: 10.1016/j.jhazmat.2010.06.027.

33. Yeo, T.H.C., Tan, I.A.W. \& Abdullah, M.O. (2012). Development of adsorption air-conditioning technology using modified activated carbon - A review. Renew. Sustain. Energy. Rev. 16(5), 3355-3363. DOI: 10.1016/j.rser.2012.02.073.

34. Nebagha, K.C., Ziat, K., Rghioui, L., Khayet, M., Saidi, M., Aboumaria, K., El Hourch, A. \& Sebti, S. (2015). Adsorptive removal of copper (II) from aqueous solutions using low-cost Moroccan adsorbent. Part I: parameters influencing $\mathrm{Cu}$ (II) adsorption. J. Mater. Environ. Sci. 6(11), 3022-3033.

35. Li, Y., Xia, B., Zhao, Q., Liu, F., Zhang, P., Du, Q., Wang, D., Li, D., Wang, Z. \& Xia, Y.(2011). Removal of copper ions from aqueous solution by calcium alginate immobilized kaolin. J. Environ. Sci. 23(3), 404-411. DOI: 10.1016/S10010742(10)60442-1.

36. Bailey, R.W. (1967). Quantitative studies of ruminant digestion. NZ J. Agric. Res. 10(1):15-32. DOI: 10.1080/00288233.1967.10423074.

37. Carpita, N.C. (1984). Fractionation of hemicelluloses from maize cell walls with increasing concentrations of al- 
kali. Phytochemistry 23(5), 1089-1093. DOI: 10.1016/s00319422(00)82615-1

38. Mehlig, J. (1941). Colorimetric determination of copper with ammonia. Ind. Eng. Chem. Anal. Ed. 13(8), 533-535. DOI: 10.1021/i560096a006.

39. Hameed, B.H., Mahmoud, D.K. \& Ahmad, A.L. (2008). Equilibrium modeling and kinetic studies on the adsorption of basic dye by a low-cost adsorbent: coconut (Cocos nucifera) bunch waste. J. Hazard Mater. 158(1), 65-72. DOI: 10.1016/j. jhazmat.2008.01.034.

40. Dawczynski, C., Schubert, R. \& Jahreis, G. (2007). Amino acids, fatty acids, and dietary fibre in edible seaweed products. Food Chem. 103(3), 891-899. DOI: 10.1016/j.foodchem.2006.09.041.

41. El Gamal, A.A. (2010). Biological importance of marine algae. Saudi Pharmaceut. J. 18(1), 1-25. DOI: 10.1016/j. jsps.2009.12.001.

42. Proctor, M.C.F. (2000). The bryophyte paradox: tolerance of desiccation, evasion of drought. Plant Ecol. 151(1), 41-49. DOI: 10.1023/A:1026517920852.

43. Yargıç, A. Ş., Yarbay Şahin, R. Z., Özbay, N., \& Önal, E. (2015). Assessment of toxic copper(II) biosorption from aqueous solution by chemically-treated tomato waste(Solanum lycopersicum). J. Clean. Prod. 88, 152-159. DOI: 10.1016/j. jclepro.2014.05.087.

44. Vafakhah, S., Bahrololoom, M. \& Saeedikhani, M. (2016). Adsorption kinetics of cupric ions on mixture of modified corn stalk and modified tomato waste. J. Water Res. Prot. 8(13), 1238-1250. DOI: 10.4236/jwarp.2016.813095.

45. Reddad, Z., Gerente, C., Andres, Y. \& Le Cloirec, P. (2002). Adsorption of several metal ions onto a low-cost biosorbent: kinetic and equilibrium studies. Environ. Sci. Technol. 36(9), 2067-2073. DOI: 10.1021/es0102989.

46. Moreira, V.R., Lebron, Y.A.R., Freire, S.J., Santos, L.V.S., Palladino, F., Jacob, R.S. (2019). Biosorption of copper ions from aqueous solution using Chlorella pyrenoidosa: Optimization, equilibrium and kinetics studies. Microchem. J. 145, 119-129. DOI: 10.1016/j.microc.2018.10.027.

47. Lacerda, E.C.M., dos Passos Galluzzi Baltazar, M., dos Reis, T.A., do Nascimento, C.A.O., Côrrea, B., Gimenes, L.J. (2019). Copper biosorption from an aqueous solution by the dead biomass of Penicillium ochrochloron. Environ. Monit. Assess. 191, 247. DOI: 10.1007/s10661-019-7399-y.

48. Mokkapati, R.P., Mokkapati, J. \& Ratnakaram, V.N. (2016). Kinetic, isotherm and thermodynamics investigation on adsorption of divalent copper using agro-waste biomaterials, Musa acuminata, Casuarina equisetifolia L. and Sorghum bicolor. Pol. J. Chem. Technol. 18, 68-77. DOI: 10.1515/pjct-2016-0031. 49. Calero, M., Blázquez, G., Dionisio-Ruiz, E., Ronda, A. \& Martín-Lara, M.A.(2013). Evaluation of biosorption of copper ions onto pinion shell. Desalination Water Treat. 51, 2411-2422. DOI: $10.1080 / 19443994.2012 .747472$.

50. Faix, O. (1992). Fourier transform infrared spectroscopy. In S.Y. Lin \& C.W. Dence(eds.), Methods in lignin chemistry (pp. 233-241). Berlin, Heidelberg: Springer Berlin Heidelberg. DOI: 10.1007/978-3-642-74065-7_16.

51. Collier, W.E., Schultz, T.P. \& Kalasinsky, V.F. (1992). Infrared study of lignin: reexamination of aryl-alkyl ether $\mathrm{C}-\mathrm{O}$ stretching peak assignments. Holzforschung 46(6), 523-528. DOI: 10.1515/hfsg.1992.46.6.523.

52. Ramavandi, B. \& Asgari, G. (2018). Comparative study of sun-dried and oven-dried Malva sylvestris biomass for high-rate $\mathrm{Cu}(\mathrm{II})$ removal from waste water. Proc. Saf. Environ. Prot. 116, 61-73. DOI: 10.1016/j.psep.2018.01.012.

53. Sinha, A., Singh, V.N., Mehta, B.R. \& Khare, S.K. (2011). Synthesis and characterization of monodispersed orthorhombic manganese oxide nanoparticles produced by Bacillussp. cells simultaneous to its bioremediation. J. Hazard. Mater. 192(2), 620-627. DOI: 10.1016/j.jhazmat.2011.05.103.
54. Langmuir, I. (1918). The adsorption of gases on plane surfaces of glass, mica and platinum. J. Am. Chem. Soc. 40(9), 1361-1403. DOI: 10.1021/ja02242a004.

55. Freundlich, H. (1907). Über die adsorption in lösungen. Z. Für Phys. Chem. 57, 385-470. DOI: 10.1515/zpch-1907-5723.

56. Yargıç, A.Ş., Yarbay Şahin, R.Z., Özbay, N. \& Önal, E. (2015). Assessment of toxic copper(II) biosorption from aqueous solution by chemically-treated tomato waste. J. Clean. Prod. 88, 152-159. DOI: 10.1016/j.jclepro.2014.05.087.

57. Haroon, H., Gardazi, S.M.H., Butt, T.A., Pervez, A., Mahmood, Q. \& Bilal, M.(2017). Novel lignocellulosic wastes for comparative adsorption of $\mathrm{Cr}(\mathrm{VI})$ : equilibrium kinetics and thermodynamic studies. Pol. J. Chem. Technol. 19(2), 6-15. DOI: $10.1515 /$ pjct-2017-0021. 